H A R VAR D

\title{
Cost of External Finance and Selection into Entrepreneurship
}

Ramana Nanda

\section{Working Paper}

08-047 


\title{
Cost of External Finance and Selection into Entrepreneurship*
}

\author{
Ramana Nanda \\ Harvard Business School \\ HBS Working Paper 08-047 \\ January 10, 2008
}

\begin{abstract}
This paper examines the extent to which the positive relationship between personal wealth and entry into entrepreneurship is due to financing constraints. I exploit a tax reform and use unique micro-data from Denmark to study how exogenous changes in the cost of external finance shape both the probability of entering entrepreneurship and the characteristics of those who become entrepreneurs. As expected, differences-in-differences estimates show that the entry rates for individuals who faced an increase in the cost of finance fell by $40 \%$ relative to those whose cost of external finance was unchanged. However, while some of the fall in entry was due to less wealthy individuals with high human capital (confirming the presence of financing constraints), the greatest relative decline in entry came from individuals with lower human capital, many of whom were above median wealth. This finding suggests that an important part of the positive relationship between personal wealth and entrepreneurship may be driven by the fact that wealthy individuals with lower ability can start new businesses because they are less likely to face the disciplining effect of external finance.
\end{abstract}

JEL Classification: D31, H24, J24, M13.

Key Words: financing constraints, entrepreneurship, entry.

*I am grateful to Niels Westergård-Nielsen at the Center for Corporate Performance and Jesper Sørensen for providing access to the data, and to the Kauffman Foundation for financial support. I am also grateful to Peter Birch Sørensen and Erik Rahn Jensen for helping me understand the tax reform, and to Peter Hougård Nielsen for help with translation. This paper has benefited from very helpful feedback from Thomas Astebro, Kevin Boudreau, Serguey Braguinsky, Rodrigo Canales, John-Paul Ferguson, Bob Gibbons, Lars Bo Jeppesen, Simon Johnson, Bill Kerr, Tarun Khanna, Nico Lacetera, Josh Lerner, Rafel Lucea, Annamaria Lusardi, Søren Bo Nielsen, Søren Leth-Petersen, Antoinette Schoar, Jesper Sørensen, Tavneet Suri and Noam Wasserman, as well as seminar participants at Carnegie Mellon, University of Copenhagen, Columbia GSB, Fuqua School of Business, Harvard Business School, INSEAD, London Business School, London School of Economics, MIT, NBER, Rotman School of Business, UCLA and Wharton. All errors are my own. 


\section{Introduction}

Entrepreneurs are, on average, significantly more wealthy than those who work in paid employment. For example, Gentry and Hubbard (2004) find that entrepreneurs comprise just under $9 \%$ of households in the US, but they hold $38 \%$ of household assets and $39 \%$ of the total net worth. Not only are entrepreneurs more wealthy, but the wealthy are also more likely to become entrepreneurs (e.g., Evans and Jovanovic, 1989; Hurst and Lusardi, 2004). This relationship between personal wealth and entry into entrepreneurship has long been seen as evidence of market failure, where talented but less wealthy individuals are precluded from entrepreneurship because they don't have sufficient wealth to finance their new ventures (Stiglitz and Weiss, 1981; Evans and Jovanovic, 1989; Gentry and Hubbard, 2004; Holtz-Eakin, Joulfaian and Rosen, 1994).

A more recent alternate view has suggested that the relationship between wealth and entrepreneurship may in fact be due to omitted variables rather than market failure. For example, Hurst and Lusardi (2004) argue that the preference for being an entrepreneur may be correlated with wealth, leading to a spurious correlation between an individual's wealth and her propensity to become an entrepreneur. Moskowitz and Vissing-Jorgensen (2002) make a similar claim, arguing that entrepreneurial choices may be driven more by preferences for risk (as in Khilstrom and Laffont, 1979), or a preference for control over the strategic direction of their own firms (as in Hamilton, 2000) than by market failure.

Understanding the extent to which the relationship between personal wealth and entrepreneurship is driven by market failure is not just of theoretical interest, but also has important policy implications, given the number of government programs aiming to promote entrepreneurial activity through financial subsidies. The inferential challenge, however, lies in the fact that one needs an exogenous change in the financing environment for entrepreneurs that is unrelated to both the opportunity cost of funding new projects and the characteristics of potential entrepreneurs. Without such an exogenous change, one cannot distinguish the substantive effect of financing constraints on entrepreneurship from other omitted variables that also affect selection into entrepreneurship. The approach used in the paper is to exploit a tax reform in Denmark that reduced the ability to expense interest payments on debt and hence increased the de facto cost of external debt finance for some individuals, while leaving the cost unchanged for others. Using this reform as the source of exogenous variation in the financing environment therefore enables me to directly study how changes in the cost of external finance affected selection into entrepreneurship.

In addition, I depart from the prior literature that has looked only at rates of entry into entrepreneurship to also examine the characteristics of individuals who choose to become entrepreneurs. This approach allows me to explicitly distinguish the extent to which individuals' decision to become an entrepreneur is associated with their wealth, as opposed to other factors affecting selection into entrepreneurship. 
I use a unique individual-level panel dataset for the analysis which is drawn from the Danish tax registers and comprises annual observations on each legal resident of Denmark. The dataset has detailed occupation codes that facilitate a very precise identification of individuals who are entrepreneurs. Further, the dataset spans the eighteen year period from 1980-1997 and has detailed information on the demographic and financial attributes of each individual. This allows me to study observable differences between individuals who choose to select into entrepreneurship as well as to construct accurate measures of each individual's (unobserved) fixed effect, based on their actual and predicted annual income in each year. I therefore also examine how unobserved individual ability differed for those who became entrepreneurs when the cost of external finance was high, relative to when it was low.

Differences-in-differences estimates highlight that entry rates for those affected by the reform fell by $40 \%$ relative to those who did not face an increase in the cost of external finance. Interestingly, however, two distinct groups of individuals were impacted by the increase in the cost of finance. First, some less wealthy individuals with high human capital were less likely to become entrepreneurs, particularly in industries that were more reliant on external finance. Although this highlights the presence of financing constraints in entrepreneurship, only $11 \%$ of the relative fall in entry was due to this group. The greatest relative drop in entry came from individuals with low human capital. In fact, just under half of the fall in entry was due to individuals with low human capital, but who were above median wealth. This second finding suggests that an important aspect of the correlation between personal wealth and entrepreneurship is driven by the fact that wealthy, but lower ability individuals can start new businesses because they are less likely to face the disciplining effect of external finance.

The second finding also helps to shed light on the why already-wealthy individuals may be sensitive to unexpected changes in their assets when starting new businesses (Hurst and Lusardi, 2004; Holtz-Eakin, Joulfaian, and Rosen, 1994). Windfall gains in assets, like the lower cost of external finance, may facilitate the founding of lower growth-potential or 'lifestyle' firms. It may also shed light on why the wealthiest individuals have been found to be relatively poor entrepreneurs (Evans and Jovanovic, 1989; Hvide and Møen, 2007) and why wealthy entrepreneurial households seem to have an unusually low return on their private equity (Moskowitz and Vissing-Jorgensen, 2002).

These results should also be of interest to policy makers. In particular, they should interest policy makers relating the financing environment for new ventures to entrepreneurial outcomes. This study suggests that policy makers aiming to subsidize entrepreneurship using cheap credit could also drive adverse selection among new entrants by encouraging those with a preference for entrepreneurship (rather than only those who are credit constrained) to select into entrepreneurship. For example, the results suggest there may be a potential risk of 'excess entry' among the wealthy if the hurdle rates to finance their new ventures are too low (de Meza 2002). In addition, the results should be of interest to those thinking about the impact of tax policy on 
entrepreneurial outcomes (Gentry and Hubbard, 2000, 2004; Cullen and Gordon, 2002) and how these policies can be used to impact both the characteristics of those becoming entrepreneurs and the distribution of talent across occupations.

\section{Financing Constraints and Entrepreneurship}

Empirical tests of financing constraints in entrepreneurship typically assume that individuals are wealth maximizers and that they choose entrepreneurship over paid employment if it yields the highest present value of future earnings. Let individual earnings for individual $i$ in sector $j$ and year $t$ be given by:

$$
Y_{i j t}=f_{j}\left(H_{i t}, W_{i t}\right)+\epsilon_{i j t} \quad j=E N T, P E
$$

where $H_{i t}$ is a vector of observed individual productivity characteristics such as education and job tenure, $W_{i t}$ is the individual's personal wealth and the two sectors are entrepreneurship and paid employment. Aside to contributing towards an individual's non-salary income in a given year, individual wealth may play an additional role in determining entrepreneurial income and hence occupational choice: since new businesses require a capital investment, the returns from a new venture can be expected to be an increasing function of the capital invested in the startup up to an optimal level. If an individual does not face financing constraints, then the amount of capital that she invests in her business would be independent of her personal wealth. If however, she did face financing constraints, then the amount she invests would be based on her personal wealth (less than the optimal level of capital), lowering her expected income from entrepreneurship, and hence lowering the probability that she would leave paid employment to become an entrepreneur.

The standard approach to testing credit constraints is therefore to run a probit model where the dependent variable takes a value of 1 if an individual who is employed in one year becomes an entrepreneur in the next. If the coefficient on individuals' personal wealth is positive, it suggests that individuals may be credit constrained (Evans and Jovanovic,1989, Gentry and Hubbard, 2004).

Subsequent research has aimed to overcome two sources of spurious correlation in such an empirical test. The first relates to the endogeneity of wealth creation: if individuals with low ability are less likely to generate savings and also less likely to become entrepreneurs, the observed correlation between personal wealth and entrepreneurship may reflect this unobserved attribute rather than the causal effect of financing constraints (Holtz-Eakin, Joulfaian, and Rosen, 1994). In order to control for such a spurious correlation, researchers have sought to find exogenous shocks to personal wealth and study their effect on selection into entrepreneurship. For example, Lindh and Ohlsson (1999) have shown that those who win lotteries are more likely to be entrepreneurs than those who do not. A related approach has used inheritances as a source 
of unexpected liquidity that reduces potential financing constraints (Holtz-Eakin, Joulfaian, and Rosen, 1994; Blanchflower and Oswald, 1998). These studies also find that unexpected shocks to personal wealth lead to higher rates of entry into entrepreneurship.

A second source of spurious correlation arises from the fact that (observed and unobserved) individual ability and preferences for entrepreneurship may be systematically correlated with personal wealth. For example, wealthy people may have lower absolute risk aversion, making them more likely to become entrepreneurs (Evans and Jovanovic,1989; Khilstrom and Laffont, 1979), or they may have a preference for being their own boss that rises with wealth (Hurst and Lusardi, 2004). Further, suppose that individuals have sector specific abilities so that:

$$
\epsilon_{i j t}=\theta_{i j}+\eta_{i j t} \quad j=E N T, P E
$$

In such a framework, if wealthier individuals are more productive as entrepreneurs than as wage employees, say because they have access to better entrepreneurial opportunities or networks (Shane, 2000), they may be more likely to systematically sort into entrepreneurship than those who are less wealthy. Each of these factors where personal wealth is systematically correlated with entrepreneurial ability or preferences would lead to a positive relationship between individual wealth and entrepreneurship even if individuals faced an exogenous shock to personal wealth. In fact, in an extreme case we may observe individual $i$ becoming an entrepreneur even when in pure income terms she is better off in wage employment. This argument has been put forth by Hamilton (2000) and Moskowitz and Vissing-Jorgensen (2002) to account for the fact that in their samples, individuals seem to become, and remain entrepreneurs, even though their income as entrepreneurs is below that of wage employees. ${ }^{12}$

\subsection{Cost of External Finance and Selection into Entrepreneurship}

The approach used in this paper to identify financing constraints is to exploit a reform that changed the financing environment for new ventures, but did not directly affect individual wealth or the opportunity cost of capital for new projects. This approach to identifying financing constraints has the attractive property of allowing me to better-account for the second source of spurious correlation outlined above.

Further, since, the reform changed financing constraints without directly impact individuals' wealth, it also allows me to explicitly examine the extent to which personal wealth, as opposed to other factors is important for determining selection into entrepreneurship. In particular, I focus on the extent to which human capital - rather than personal wealth - may be the basis of

\footnotetext{
${ }^{1}$ Although Moskowitz and Vissing-Jorgensen (2002) do not find entrepreneurial income to be below that of wage employment, they argue that the income for entrepreneurial households that they observe is still below the income premium one would expect them to have over wage employees holding public equity portfolios, given that entrepreneurial households invest the vast majority of their wealth into a single business, thereby holding highly concentrated, risky, and illiquid private equity portfolios.

${ }^{2}$ Hurst and Lusardi (2004) also point to this explanation in trying to reconcile the fact that in their sample, very wealthy households show a strong positive relationship between wealth and entry into entrepreneurship, while this relationship does not exist for less wealthy households.
} 
selection into entrepreneurship. To see why this might be the case, note that for a project with a fixed capital investment, or an environment where the returns to human capital are higher in the entrepreneurship sector, individuals with higher human capital and ability will be more likely to enter entrepreneurship. This implies that while one response of an increase in the cost of finance could be a fall in the entry of those "marginal" individuals who have less capital, another response might be the fall in entry of those who have lower human capital or lower ability. While the former is an example of market failure as portrayed in the literature, the latter is not. This study therefore helps to shed light on these two distinct selection mechanisms that are harder to study when looking only at unexpected shocks to personal wealth.

\subsection{Danish Tax Reform}

The Danish tax reform of 1987 was part of a series of such tax reforms across OECD countries in the mid-1980s, including the US reform of $1986 .{ }^{3}$ One of the important changes resulting from the reform was the treatment of interest expense on personal debt. While the tax structure prior to 1987 allowed individuals to expense interest on their personal debt at their marginal tax, this provision was removed following the reform. Thus, while prior to 1987, someone in the top tax bracket - whose marginal tax rate then was $73 \%$ - could deduct $73 \%$ of the interest expense on their debt, the maximum they could deduct after 1987 was 52\% (Hagen and Sørensen 1998; Jensen 2002).

This change in policy related to expensing interest on personal debt would have been particularly hard for owners of unincorporated businesses, whose cost of external financing increased substantially following the reform. Recognizing this, the tax reform also included a special provision for such entrepreneurs (known as the "company tax scheme") that allowed them to continue expensing interest payments on debt related to their unincorporated business at their marginal tax rate, as long as they could show - using additional accounting procedures - that the debt was used for running the business. In practice, the company tax scheme was complicated and poorly advertised, which meant that many entrepreneurs faced a de facto increase in the cost of finance that was much larger. Note, however, that even those individuals who availed of the company tax scheme faced an increase in the cost of external finance since the tax law

\footnotetext{
${ }^{3}$ Denmark's tax reform of 1987 was the first major tax reform in the country since the early 1900 's and was part of a series of such reforms that took place across Scandinavia and many OECD countries over the late 1980s and early 1990s, including the US tax reform of 1986. Following the reform in 1987, Denmark was the first Nordic country to move towards a system of 'dual income taxation', where capital and labor income are taxed at separate rates rather than at the same rate as is done in the system of 'global income taxation'. Although first introduced in Denmark in 1987, this feature was subsequently adopted by the other Nordic countries over the next 5 years.

Denmark's adoption of the dual income tax is credited to the efforts of a Danish professor, Niels Christian Nielsen who argued in favor of a flat tax on capital income - that would be equal to the corporate tax rate combined with a progressive tax rate on the remaining (labor income) for an individual. Nielsen was a member of the influential 'Thorkil Kristensen Committee' advising the government, as well as on a committee of tax experts set up by the Danish Savings Bank Association in 1984 to study the Danish tax system and both of these committees pushed for a series of tax reforms along the lines of the dual income tax (Sørensen, 1998). This led to an agreement among the Danish political parties to change the tax system in late 1985, that took effect as of the beginning of 1987 and were phased in over the next two years.
} 
involved a fall in the national tax rates (although an increase in local government taxes implied that the overall tax rate remained very similar).

Thus, while overall tax rates faced by the individuals remained roughly constant, potential (and current) entrepreneurs faced a steep increase in their cost of external finance if they were in one of the two higher income tax brackets. These details can be seen from the table below.

Interest Tax Shield on Debt

\begin{tabular}{lccc}
\hline & $\begin{array}{c}\text { Highest Tax Bracket } \\
\text { (80-100th Pctile } \\
\text { in Income) }\end{array}$ & $\begin{array}{c}\text { Middle Tax Bracket } \\
\text { (40-80th Pctile } \\
\text { in Income) }\end{array}$ & $\begin{array}{c}\text { Lowest Tax Bracket } \\
\text { (0-40th Pctile } \\
\text { in Income) }\end{array}$ \\
\hline Pre 1987 & $73 \%$ & $62 \%$ & $48 \%$ \\
Post 1987 & $52-69 \%$ & $52-58 \%$ & $52 \%$ \\
\hline
\end{tabular}

For example, an individual in the highest tax bracket who borrowed 10,000 Kroner at $10 \%$ would have had an effective interest rate of just $2.7 \%$. This increased to an effective interest rate of between $3.1 \%$ and $4.8 \%$ following the reform, which implied an increase of between $10 \%$ and $75 \%$ over the interest payments prior to the reform.

Since personal debt is used by the vast majority of entrepreneurs using external finance (Fluck, Holtz-Eakin and Rosen 1998) and constitutes over $60 \%$ of the external financing of new ventures (Petersen and Rajan, 1994; Black and Strahan, 2002), the change in the cost of debt financing serves as a useful way to study the extent to which the cost of external finance impacts entry into entrepreneurship. Moreover, since individuals in two tax brackets faced an increase in the cost of external finance but the third group did not, this facilitates a differences-in-differences empirical specification for my analysis.

\section{Data}

\subsection{Description of Data}

I use a matched employer-employee panel dataset for this study that is a significant improvement over data used in most prior studies on financing constraints. The data is drawn from the Integrated Database for Labor Market Research in Denmark, which is maintained by the Danish Government and is referred to by its Danish acronym, IDA. IDA has a number of features that makes it very attractive for this study.

First, the data is collected from government registers on an annual basis, and has detailed micro data on the labor market status of individuals, including their primary occupation. An individual's primary occupation in IDA is characterized by the fraction of income earned from that occupation over the prior year. Individuals are therefore identified as business owners if the majority of their income in that year came from their business. This allows me to identify entrepreneurs in a much more precise manner than many prior studies. For example, I can 
distinguish the truly self-employed from those who are unemployed but may report themselves as self-employed in surveys. I can also distinguish the self-employed from those who employ others in their firm. Finally, since my definition of entrepreneurship is based on an individual's primary occupation code, I am also able to exclude part-time consultants and individuals who may set up a side business in order to shelter taxes from my definition of entrepreneurship.

Second, the database is both comprehensive and longitudinal: all legal residents of Denmark and every firm in Denmark is included in the database. In this extract, I have annual observations on each individual for 18 years from 1980-1997. This is particularly useful in studying entry into entrepreneurship where such transitions a rare event. It also allows me to control for many sources of unobserved heterogeneity at the individual level.

Third, the database links an individual's ID with a range of other demographic characteristics such as their age, educational qualifications, marital status, parents' occupational codes, as well as important financial data, including annual salary income, total income, and the value of their assets and debt. This facilitates a study of the basis of selection into entrepreneurship.

While there are several benefits to using this data for my study, there may be concerns about the external validity of a study that is based on information from a relatively small country such as Denmark. I address some of these concerns in Table A1 in the Appendix - by looking at how the rates of self-employment in Denmark compares to the US, and where available in other European countries. Moreover, as I show later in the analysis, the concentration of wealth and income among entrepreneurs is also present in Denmark, as it is in the US. These comparisons should provide confidence that the data I use has external validity beyond Denmark, at least to other OECD and developed economies.

\subsection{Definition of Entrepreneurship}

There are two main types of individuals classified as business owners in IDA- those who are self employed and those who are self employed with at least one employee. I focus the analysis on individuals with at least one employee, as these are probably individuals who need to make more capital investment in their businesses than those who are self employed. However, I do show in several of the tables, that the results are robust to including individuals who are self-employed without employees.

I define transitions to entrepreneurship as taking place when an individual who is employed in a given year becomes an entrepreneur in the subsequent year. That is, I study transitions to entrepreneurship when an individual is classified as being in paid employment in year $t$

and becomes an entrepreneur in year $t+1$. I therefore treat as censored, individuals who were unemployed, students or self-employed in year $\mathrm{t}$, but became employers in year $\mathrm{t}+1$. 


\subsection{Sample used for the Analysis}

One of the important factors predicting entry into entrepreneurship is individuals' tenure at their job. This information is not directly available in the IDA database, but given the panel structure of the data, can be calculated from the dataset for those individuals who started a new job at the beginning of any period. I therefore choose the sample for my study by taking all individuals who switched into a new firm in 1981. That is, I look at all individuals who were employed in 1981 but were not employed at the same firm in 1980. I then restrict this sample to include individuals who are between 16 and 42 years of age in 1980, so that no individual in my sample is younger than 16, or older than 60. Approximately 270,000 individuals (or $15 \%$ of all employed individuals in 1981) met this criteria. I then created a panel dataset comprised of all these individuals for the period 1981-1997. Note that since I am only interested in transitions from employment to entrepreneurship, I exclude individuals in years in which they are unemployed, or self employed. This subset of the main IDA database, with annual observations on each of the individuals in the sample as above, forms the basis for my analysis. ${ }^{4}$

\subsection{Descriptive Statistics}

I report descriptive statistics on my sample in Table 1 . Table 1 breaks down the sample by those who transitioned to entrepreneurship in the following year, and those who did not. As can be seen from Table 1, individuals who become entrepreneurs in the following year have 1.5 times the household assets than those who do not become entrepreneurs, and earn a third more. Table 1 another aspect of the individuals who become entrepreneurs: They are more likely to be employed as directors, or senior white collar employees in the year before they become entrepreneurs compared to those who do not transition. Further, within the group of blue collar workers, they are more likely to be skilled rather than unskilled workers. This suggests that individuals with higher human capital are selecting into entrepreneurship, a fact that is confirmed later in the analysis. The probability that an individual who is employed becomes an entrepreneur in the subsequent year is $0.35 \%$ for the overall population, but $0.58 \%$ for those in the 80-100th percentile of income. ${ }^{5} \quad$ This is consistent with prior studies looking at the role of credit constraints that find a positive relationship between wealth or income and rates of entrepreneurship (Jovanovic and Evans, 1989; Hubbard and Gentry, 2004; Hurst and Lusardi,

\footnotetext{
${ }^{4}$ Note that since there is a concern that the results may be driven by the sampling strategy used for the analysis, I also run robustness checks on the entry rate analyses (reported in Tables 2,3 and 4 ) by creating a repeated cross section by sampling $10 \%$ of the population in each year. The results are robust to this alternative sampling approach. I also find that number of switchers in my sample is representative of worker flows in Denmark in this period (Albaek and Sorensen 1998).

${ }^{5}$ These transition probabilities are smaller than those found in the US, where estimates from the Evans and Jovanovic (1989) and Hurst and Lusardi (2004) are around 4\%. Part of this difference lies in the difference in definition (if I include self-employed individuals, the transition probability in my sample rises to $1 \%$ ). Part of the difference also lies in the more stringent definition of those being classified as entrepreneurs in this dataset (only those whose primary income is from their business), as well as the difference in register-based data compared to survey data, where some unemployed individuals are likely to classify themselves as self-employed.
} 
2004).

\section{Results}

\subsection{Relationship between Personal Wealth and Entrepreneurship}

I first explore the association between individual wealth and transition into entrepreneurship in greater detail, by running logit models of transition into entrepreneurship. The basic estimation is:

$$
\operatorname{Pr}\left(E_{i t+1}=1\right)=F_{L}\left(\beta_{0}+\gamma_{i} X_{i t}+\phi_{t}+\psi_{j}+\varphi_{c}+\eta_{o}+\epsilon_{i t}\right)
$$

where $\operatorname{Pr}\left(E_{i t+1}=1\right)$ is the probability that an individual who is employed in a given year becomes an entrepreneur in the subsequent year conditional on right-hand-side variables, $F_{L}$ is the cumulative logistic distribution function, $X_{i t}$ is a matrix of individual- and firm-level control variables, and $\phi_{t}, \psi_{j}, \varphi_{c}, \eta_{o}$ refer to year, industry, county and occupation-code fixed effects, respectively. Standard errors are clustered at the individual level. I report the results of equation (3) in Table 2. Model 1 shows that both higher personal assets and higher personal debt are associated with subsequent entry into entrepreneurship. In model 2, I add other financial covariates and in model 3, a range of demographic and educational controls. The coefficients on personal assets and debt remain highly significant. The coefficients on logit models facilitate a direct look at the economic magnitude of the coefficients. The coefficient on log assets implies that a $1 \%$ increase in log assets (approximately a $10 \%$ increase in assets at the mean) implies a $8.7 \%$ increase in the odds of being an entrepreneur $(\exp (0.084)) .{ }^{6}$ Although all the models include Industry (SIC1), Year, Region, and occupation code fixed effects, I also run the regressions on a restricted set of industries (manufacturing, retail and wholesale trade, and services) to validate my results. These are not reported, but confirm the same findings as model 3. Column 4 has the same model as column 3, but with a broader definition of entrepreneurship that includes those who transition to self-employment in addition to those who transition to becoming employers. Again, the results on personal wealth remain constant, although this model highlights that the types of individuals becoming self employed are somewhat different than those becoming employers. They are less like to have university education, and less likely to be in the highest income bucket. One concern with these results is that they may not apply for the highly educated, potential technical entrepreneurs in the economy. To address this concern, column 5 reports the results of the model run in Column 4, but restricting the sample to individuals who had a university degree in 1981. Again, the value of an individuals' household assets is positively associated with the probability of becoming an entrepreneur.

\footnotetext{
${ }^{6}$ Note that the coefficients on logit models can be interpreted as the log-odds of becoming an entrepreneur. This is perhaps more intuitive than examining the marginal effects since baseline odds of becoming an entrepreneur are so low. As a comparison, the marginal effect of a unit increase in log assets (computed at the mean) is $0.02 \%$. To put this in perspective, however, the predicted probability of entry is just over $0.2 \%$, implying, as with the odds ratio, that a $1 \%$ increase in log household assets increases the probability of entry by about $10 \%$.
} 
As outlined above, one possibility for the association between wealth and entry reported in Table 2 is that there is some unobserved individual attribute that makes some people more likely to be wealthy and also be more likely to become entrepreneurs. To check this, I add in individual fixed effects into the models. I report the results of these conditional fixed effects logit models (i.e. individual fixed effects models) in Table 3. These models look at whether there is an association between wealth and entrepreneurship even within individuals' careers. ${ }^{7}$ As can be seen from the results in Table 3, the association between personal assets and entry into entrepreneurship is present even within individuals' careers, so that individuals are more likely to transition into entrepreneurship when they have higher personal assets. As with Table 3 , the coefficients on personal assets are stable and consistently significant across the different samples for which the models were run. As with Table 2, the results are shown to hold for the broader definition of entrepreneurship, that includes self-employed individuals without employees (column 4) and for individuals with greater human capital (column 5). One interesting point to note is that while having a university degree was uncorrelated with entering entrepreneurship in the cross section (and negatively associated with entry into self-employment), the individual fixed effects models highlight that, in fact, getting a university degree is strongly positively associated with becoming an entrepreneur and with becoming self-employed. Getting a university degree increases the odds of becoming an entrepreneur by over $300 \%$.

\subsection{Differences-in Differences Estimates}

Although these results so far strongly suggest that personal wealth is important for entering entrepreneurship, there is still a chance that an omitted variable that is correlated with wealth is driving the relationship, rather than wealth itself. I therefore move to a differences-indifferences specification, looking at the entry rates of those who faced an increase in the cost of external finance relative to those who did not. ${ }^{8}$ The findings can be most easily seen by looking at Figure 1. Figure 1 reports the rates of entrepreneurship before and after the reform, normalizing the entry rates to be the same in 1983. It shows that the entry rates for the lowest income bracket remained relatively constant over the period (and, if anything, rose slightly following the reform). On the other hand, entry rates for those in the two higher income brackets fell about $40 \%$ following the reform. The differential trends for these income brackets suggest that the cost of external finance played a substantive role in impacting entry following the reform. However,

\footnotetext{
${ }^{7}$ These regressions only include individuals who transitioned into entrepreneurship at some point in the sample period since including individual fixed effects requires variation in the dependent variable in order for the model to be identified (and hence have a much smaller sample size).

${ }^{8}$ Since the cost of external financing is based on income, and income is based on the cost of financing, one might imagine that entrepreneurs deliberately lower income in order to take advantage of a different tax bracket. I account for this possibility explicitly in my empirical strategy in that I do not use a regression discontinuity design but instead choose income buckets that broadly correspond to the cut-offs for the tax brackets. Given that there are only three tax brackets, my assumption here is that the cost of strategically choosing income to maximize the benefits from the cost of external capital are only worthwhile for individuals on the margins of the tax brackets but not for the vast majority of individuals I study.
} 
in order to control for covariates, I next estimate the full difference-in-differences specification outlined below:

$$
\begin{aligned}
\operatorname{Pr}\left(E_{i t+1}=\right. & 1)=F_{L}\left(\beta_{0}+\beta_{1} 40-80\right. \text { PCTILE } \\
& \beta_{3} \text { POST }_{t} * \beta_{2} \text { 80-80-100PCTILE } E_{i t}+ \\
& \left.+\gamma_{i} X_{i t}+\phi_{t}+\psi_{j}+\varphi_{c}+\eta_{o}+\epsilon_{i t}\right)
\end{aligned}
$$

The variable POST is a dummy variable that takes a value of 1 from 1987 onwards and zero until 1986. 40-80 PCTILE and 80-100 PCTILE are dummy variables that take a value of 1 if the individual is in one of the higher income brackets (affected by the reform). The differencesin-differences estimate is identified by interacting the POST variable with the income bucket of the individual in each year, to see how the propensity for entrepreneurship for individuals in the higher income brackets changed in the post period relative to that of individuals in the lower income brackets. ${ }^{9}$ The two coefficients of interest therefore are $\beta_{3}$ and $\beta_{4}$, which report the entry rates of individuals in the two higher income brackets in the post period, relative to the entry rates of individuals in the lowest income bracket. As before, standard errors are clustered at the individual level.

Table 4 reports the results of these differences-in-dfferences regressions, controlling for covariates. Models 1 and 2 report the differences-in-differences estimates on entry using the more conservative definition of entrepreneurship - that is only including business owners with at least one employee. Since the two higher income groups faced an increase in the cost of external finance due to the reform, we should expect them to have a fall in entry relative to the base category, the 0-40 Percentile of Income. This is indeed the case. Column 1 reports results for the full sample, including industry, year, region and occupation code fixed effects. The magnitude of coefficients $\beta_{3}$ and $\beta_{4}$ imply that the odds of entering entrepreneurship for individuals in these income groups fell $40-45 \%$ following the reform.

Column 2 reports results for just two years, one before and the other after the reform, at similar points in the business cycle, to avoid concerns of standard errors being too small due to serial correlation (Bertrand, Duflo and Mullainathan 2004). The results are robust to this specification. Columns 3 and 4 compare entrepreneurship in industries with a greater dependence on external finance to those that rely less on external finance. ${ }^{10}$ As can be seen from columns 3 and 4, the effect is stronger for those entering industries that are more dependent of external finance, but there is also a significant effect on industries that are less dependent on external finance.

\footnotetext{
${ }^{9}$ Note that the POST dummy is fully absorbed in this specification which includes year fixed effects.

${ }^{10}$ In order to calculate this measure of external dependence, I follow Rajan and Zingales (1998) to calculate a measure of external financial dependence of industries at the SIC2 level, using data on US public firms over the period 1990-2000. I then map this measure of external dependence to the industry codes in the IDA dataset. An industry is then classified as financially dependent if industry has above median dependence on external finance.
} 
Finally, I investigate whether the effect of the reform had a differential effect on individuals transitioning to entrepreneurship compared with other types of labor market transitions, using a multinomial logit models. I report the results of the multinomial logit models in Appendix 2. The multinomial logit models highlight that the results present for entry into entrepreneurship are not secular trends impacting all forms of labor-market transitions, and in fact are unique to those becoming entrepreneurs or self-employed. The base category in the multinomial regression is individuals who remain in the same job as they were in the previous year. Column 1 reports coefficients for those who become entrepreneurs with at least one employee, Column 2 reports the coefficients for individuals who become self employed, and Column 3 reports the results for individuals who switch jobs. Looking across the columns at the coefficients on "POST X 40-80 PCTILE" and "POST X 80-100 PCTILE" shows that the effect is strongly negative for those who become employers, less strong for those who become self-employed, and in fact is positive for those who switch jobs. In unreported regressions, I find that these differences are accentuated for industries that are more dependent on external finance (for example, the difference between employers and self-employed is also significant). These results suggest that the reform had an impact on those occupations requiring investments, particularly in those industries dependent on external finance.

\subsection{Wealth vs. Human Capital as the basis for Selection into Entre- preneurship}

Although the results thus far indicate that changes in the cost of external finance have a substantive impact on entry into entrepreneurship, they do not shed light on the basis of selection into entrepreneurship. In particular, they do not identify whether it is only the less wealthy individuals who are the ones who are reacting to the change in external finance by cutting back on entering into entrepreneurship. While prior studies have had to assume that it is the talented, less wealthy individuals who are precluded from becoming entrepreneurs due to financing constraints, the fact that the change in the financing constraint due to the reform did not directly affect individuals' personal wealth allows me to directly investigate the extent to which personal wealth, as opposed to other factors was important for individuals' decision to select into entrepreneurship. ${ }^{11}$ In particular, I investigate the extent to which those who are most impacted by the reform are those with high entrepreneurial ability, but with low wealth - that is the type of people policy makers may be most concerned about in terms of a market failure.

I therefore proxy for entrepreneurial ability using three different methods. First, I look

\footnotetext{
${ }^{11}$ The distinction between an individual's income bracket and their wealth is important in this context. In particular, if the correlation between the measure of income and wealth is very high, then the ability to distinguish the role of wealth in the selection decision will be limited since in that case the wealthiest individuals would also face the highest increases in the cost of finance. The correlation between an individual's average assets and average total income over the period 1981 to 1997 is about 50\%. The correlation between an individual's total income and household assets is $35 \%$ and the correlation between their average income and their household assets in 1981 is $24 \%$. This allows me to separate the effect of income from wealth and therefore to study how people across wealth levels reacted to the differential change in the cost of finance (based on their income bracket).
} 
at an observable measure of human capital by grouping people on whether or not they have a university degree. Second, I calculate their individual fixed effect from an income regression spanning their earnings over an eighteen-year period, and use this fixed effect to proxy for their fixed unobserved individual ability. Finally, I account for self selection into entrepreneurship based on sector-specific abilities (that is, where entrepreneurial ability is allowed to be different from ability in paid employment) by running Heckman selection models. Perhaps surprisingly, each of these results suggests that in fact many of the individuals who were sensitive to changes in the cost of finance were those with lower entrepreneurial ability, rather than those with just low wealth.

\subsubsection{Observable Measures of Human Capital}

In order to examine the extent to which human capital played a role in the decision to select into entrepreneurship, I bucket people based on their income bracket and whether they had a university degree. For simplicity, I now treat individuals in the two higher income brackets together. I therefore have four categorical variables defining individuals based on whether or not they had a university degree and whether or not they were in the income bracket that was affected by the reform. This allows me to estimate the following specification:

$$
\begin{aligned}
\operatorname{Pr}\left(E_{i t+1}=\right. & 1)=F_{L}\left(\beta_{0}+\beta_{1} U N I-0-40_{i t}+\beta_{2} U N I-40-100_{i t}+\beta_{3} N O U N I-40-100_{i t}\right. \\
& +\beta_{4} P O S T_{t} * U N I-0-40_{i t}+\beta_{5} P O S T_{t} * U N I-40-100_{i t}, \\
& \left.+\beta_{6} P_{\text {POST }} * \text { NOUNI-40-100 } i t+\gamma_{i} X_{i t}+\phi_{t}+\psi_{j}+\varphi_{c}+\eta_{o}+\epsilon_{i t}\right)
\end{aligned}
$$

where UNI characterizes individuals who have a university degree, NOUNI those who have no university degree, 0-40 defines whether they were in the income bracket unaffected by the reform and 40-100 defines whether they were in an income bracket that was affected by the reform. The omitted category is low wealth individuals without a university degree in the 0-40 income percentile. Each of the three categorical variables is then interacted with the POST dummy. ${ }^{12}$ The main coefficients of interest are $\beta_{5}$ and $\beta_{6}$. If human capital is important as a basis of selection into entrepreneurship, the coefficient on $\beta_{6}$ should be more negative than that of $\beta_{5}{ }^{13}$ I run these regressions on the full sample, and then also on subgroups of individuals based on their household wealth.

In order to look at household wealth in the selection decision, I segment individuals based on whether they were above or below median household wealth. Two different measures of household wealth could be used here. The first is where wealth is measured in the year prior

\footnotetext{
${ }^{12}$ Note that as before the year fixed effects fully absorb the post dummy.

${ }^{13}$ Note also that the coefficient on $\beta_{4}$ allows us to look at the extent to which the baseline comparison is accurate. Since those in the 0-40 category were unaffected by the reform, we should not see a significant difference among the reaction of those with high versus low human capital in this group. Hence, the coefficient on $\beta_{4}$ should be insignificant from zero.
} 
to their potential transition to entrepreneurship, that is where wealth is lagged one year. The second is one in which they are segmented based on their household wealth in 1981 . An individual's wealth in 1981 is correlated with their average wealth across the period at $75 \%$, making the results very similar using the two different measures. To be conservative, however, the results reported in Tables 5 and 6 are based on measure where individuals are segmented on their household wealth in 1981.

Using these two different segmentations allows one to compare the extent to which wealth and human capital are important in the selection decisions of individuals. In particular, if wealth is an important basis of selection, we should see a decline in entry coming from individuals with low wealth, regardless of their human capital. If ability is an important basis of selection, then we should see a decline in entry coming from individuals with low ability regardless of their wealth. It is of course possible, that they both matter, but differently for different subgroups. This is in fact what we see.

Table 5 reports the results of this estimation. Column 1 reports the results for the full sample, Columns 2 and 3 compare those who are above median wealth to those who are below median wealth, and columns 5 and 6 compare those working in financially dependent industries to those in less dependent industries. As can be seen from looking across the columns in Table 6 , there is a consistent decline in entry among those without a university degree including those who are above median wealth. The marginal effects for the decline in entry are greater for those who do not have a university degree compared to those with a university degree. For example, even for those who are below median wealth, Wald tests reject the hypothesis that the coefficient on these individuals is the same as that on the individuals without a university degree. I estimate the extent to which the fall in entry was due to each of the four buckets by multiplying the number of individuals in each category over the post period by the imputed fall in entry (based on the coefficients $\beta_{5}$ and $\beta_{6}$ in columns 2 and 3). This calculation suggests that about $11 \%$ of the total fall in entry was due to individuals with high human capital, but low wealth, $38 \%$ was due to those with low wealth and low human capital, $4 \%$ was due to those with high human capital and high wealth. The greatest share of the fall in entry (47\%) came from individuals with high wealth, but low human capital.

While individuals with a university degree faced lower declines, and in general were not significantly affected by the reform, the decline among those with high human capital, but low wealth came mainly from individuals entering industries dependent on external finance. That is, less wealthy individuals with a university degree but entering industries less dependent on external finance did not face the same decline in entry following the reform. Again, this highlights that while the majority of those cutting back entry were low ability individuals, some individuals with high human capital but low wealth were adversely affected by the reform. 


\subsubsection{Unobserved Individual Ability}

Much of individuals' ability is unobserved. In order to capture an element of this unobserved individual ability, I exploit the panel structure of the data, and the detailed individual-level observable data to back out individual fixed effects from an income regression. Each individual's fixed effect is then used to serve as proxy for their unobserved ability. I first run a fixed effects regression of the form:

$$
Y_{i t}=\alpha+\theta_{i}+\gamma_{i} X_{i t}+\epsilon_{i t}
$$

where $Y_{i t}$ is each individual's total income in year t and $X_{i t}$ is a matrix of observables, like those used in the regressions in Table 2, including the full set of industry, year, region and occupation code fixed effects. In addition to these, I include an individual fixed effect, $\theta_{i}$. Each individual's estimated fixed effect can then be 'backed' out from the fixed effects regression shown in (6).

In Table 6, I report the results of individual ability proxied by these individual fixed effects and categorized in the same manner as for the results reported in Table 5. That is, I categorize individuals into two distinct groups based on whether they were above or below median fixed effects. Each of these two categories is further split by the income group of that individual in each year and interacted with the post period dummy, yielding the same estimation structure outlined in equation (5). The only difference, however, is that those with high human capital as defined as those with high unobserved fixed effects, rather than those with a university degree. The specification is therefore:

$$
\begin{aligned}
\operatorname{Pr}\left(E_{i t+1}=\right. & 1)=F_{L}\left(\beta_{0}+\beta_{1} \text { HIGH-0-40 } i t+\beta_{2} H I G H-40-100_{i t}+\beta_{3} L O W-40-100_{i t}\right. \\
& +\beta_{4} P O S T_{t} * H I G H-0-40_{i t}+\beta_{5} P O S T_{t} * H I G H-40-100_{i t} \\
& \left.+\beta_{6} P_{\text {POST }} * L O W-40-100_{i t}+\gamma_{i} X_{i t}+\phi_{t}+\psi_{j}+\varphi_{c}+\eta_{o}+\epsilon_{i t}\right)
\end{aligned}
$$

Given the computational difficulty of estimating 270,000 fixed effects, I examine the role of individual fixed effects within the group of individuals with high human capital - that is within the group of individuals who had a university degree in 1981. Table 6 reports the results. Note that this table also reports results for the broader definition of entrepreneurship that also includes self-employment so that the coefficients can be estimated more precisely. The results using the more narrow definition of entrepreneurship that only includes employers yields similar results, but is less precisely estimated due to the small number of such individuals in the sample. ${ }^{14}$

It can be seen from Table 6 that the coefficients follow a similar pattern to those in Table 5. It is the individuals with the low unobserved ability rather than those with the low wealth

\footnotetext{
${ }^{14}$ Two different approaches were used to compute fixed effects for those who became entrepreneurs: including the years in which they earned entrepreneurial income, and excluding those years. The fixed effect results computed using these two different approaches were correlated at $97 \%$. The results reported in Table 7 include income for those individuals in all years.
} 
who are most likely to reduce entry into entrepreneurship following the reform when financing constraints increased. Moreover, the effect is stronger for those entering industries with a higher dependence on external finance. In fact, in this estimation, the individuals with high ability do not seem to be adversely affected by the reform, even among those who are below median wealth.

\subsubsection{Allowing for Heterogeneous, Sector-Specific Ability}

One of the potential concerns with using individual fixed effects to account for unobserved ability is that it does not account for sorting into entrepreneurship based on sector specific abilities, as in equation (2). Heckman selection models (Heckit models) explicitly account for this non-random

selection. I run the selection models separately for those in the 'treatment' and 'control' groups for both the pre-reform period and the post-reform period, using as my instrument the dummy variable for whether an individual's parents were entrepreneurs. These results are reported in Table 7 .

The coefficient on the inverse mills ratio compares the returns for those who entered entrepreneurship with the expected returns for the individuals who did not select in (Hamilton 2000). Looking across the coefficients on $\lambda$ in the post period, one can see that the coefficient becomes significantly positive in the post period for wealthy individuals following the reform, while it becomes negative (though not significant) for individuals who are less wealthy. Again, these results are consistent with the results in the prior Tables - among the wealthy individuals, the decline in entry among lower ability individuals implies that the quality of entrepreneurs increased following the reform. Among less wealthy individuals, however, the negative sign potentially suggests the presence of a constraint preventing talented individuals from becoming entrepreneurs (Carneiro and Heckman, 2002). These results are also consistent with a view that there are two distinct subgroups affected by the increase in the cost of capital. The first included some talented but less wealthy individuals who may have faced financing constraints. The second included lower ability individuals who entered because the cost of external finance was low but who cut back when the cost of external finance increased.

\subsection{Robustness Checks}

\subsubsection{Business Cycle Effects}

A potential concern with the results are that they are driven by business cycle effects. In particular, the reduction in the ability to expense personal debt also meant that mortgage payments increased dramatically, creating a reduction in the demand for large houses and hence a sharp fall in the property prices, particularly at the high end. This fall in asset prices also coincided with a recession that lasted from 1987 till 1991. I include year fixed effects in all the specifications to control for year-specific fluctuations in the business environment. Note 
also that period under study spans 1981 to 1996 which includes two and a half business cycles (one prior to and another one and a half post the reform). In particular, the property prices increased from 1992 onwards and in fact were higher in 1996 than they were in 1986 prior to the crash in prices. These business cycle effects do not completely explain the results as can be seen clearly from Figure 1.

\subsubsection{Was it a reduction in 'Tax Dodging'?}

Another concern with the results I have reported is that the tax reform may have also reduced tax dodging, so that individuals who had an incentive to set up a firm to dodge taxes now no longer needed to. It is unlikely that this is the case: prior to the reform, there was no separation between taxation of unincorporated businesses and personal income, so there was in fact no incentive for individuals to set up businesses specifically to dodge taxes on personal income. The ability to take on business debt for example, did not add any benefit for individuals in terms of tax breaks. They could take the loan for their own consumption and get the same tax shield on interest expense. Further, incorporating the company did not yield any benefits either.

Although there was still an incentive to set up a business to generate tax breaks or shelters (such as a car for the business that could then be written off as business expense), these types of 'tax shelter' businesses are explicitly excluded from my analyses. I only include those individuals whose primary source of income is from entrepreneurship, and further, those who have at least one employee. This reduces the likelihood of individuals who 'found a business on the side' as being classified as entrepreneurs.

\subsubsection{Other Incentive changes due to the Tax Reform}

It is possible that the change in the overall structure of the tax rates may have had alternative incentive changes that impacted individuals in a manner similar to that of a financing constraint. For example, Carroll, Holtz-Eakin et al (2000) argue that an increase in tax rates should reduce the propensity to become an entrepreneur because of the effect on the cash flow of businesses, as well as the incentive to exert effort as an entrepreneur. Gentry and Hubbard (2000) support this view. It is unlikely that the tax rates had a direct impact on entrepreneurship because overall tax rates remained roughly constant across this period due to increases in local taxes. If anything, the results in this paper are counter to the predictions of Caroll, Holtz-Eakin et al (2000) and Gentry and Hubbard (2000), highlighting that the role of financing constraints in this context is an important driver of entry into entrepreneurship.

Gordon (1998) and Cullen and Gordon (2002) argue that in fact high marginal tax rates on unincorporated businesses relative to the corporate tax rate may in fact increase entrepreneurial activity. Their argument is that the high marginal tax rates on unincorporated businesses serve as an insurance policy against business failure because they allow businesses to write off business 
losses against personal income in the event that they fail. They argue that the value of this insurance increases as the wedge between personal tax rates and corporate tax rates increase, and hence lower marginal tax rates may in fact dampen entrepreneurial activity. While the overall entry rates are consistent with this mechanism, there was no increase in the founding of incorporated businesses relative to unincorporated businesses across this period. Further, the greater decreases in entry for those in industries more dependent on external finance (Table 4) suggests that the effect runs through an increase in the cost of external finance.

\section{Conclusions}

The relationship between individual wealth and entry into entrepreneurship has long been seen as evidence that less wealthy individuals are precluded from entrepreneurship because they don't have sufficient private wealth to finance their new ventures. Recent research has challenged this view, arguing that the relationship may not necessarily be a consequence of market failure.

In order to examine the extent to which personal wealth is a barrier to entrepreneurship, I exploit a tax reform that changed the de facto cost of debt finance for potential entrepreneurs, to see how this exogenous change in the cost of external finance impacted both the rate of entry and the characteristics of individuals who chose to become entrepreneurs. This approach not only helps to overcome potential omitted variables in studying entry rates of individuals, but also allows me to explicitly examine the extent to which individuals with low wealth, as opposed to other characteristics, are most affected by the change in external finance.

I find that entry fell for individuals who faced an increase in the cost of external finance due to the tax reform, showing that in fact the cost of external finance plays a substantive role in impacting entry into entrepreneurship. Two distinct subgroups of individuals were impacted by the reform. First, some less wealthy individuals with high human capital were adversely impacted by the reform, particularly in industries that relied more on external finance. This subgroup highlights the presence of financing constraints in entrepreneurship but accounted for only $11 \%$ of the total relative decline in entrepreneurship. Just under half the decline in entry came from wealthy individuals with low human capital who had chosen to enter when the cost of external finance was low, but did not enter when the cost of finance increased. The increase in the cost of capital due to the reform caused these marginal, lower-ability individuals to select out of entrepreneurship.

These results have several important implications. First, they contribute to the current literature on financing constraints in entrepreneurship by providing direct evidence of an alternative mechanism through which individuals select into entrepreneurship. The results highlight that the higher rates of entrepreneurship prior to the reform were driven in part by lower ability individuals who could indulge their preference for entrepreneurship because the cost of external finance was low. The increase in the cost of finance raised the hurdle of entry, leading lower 
ability individuals (rather than just lower wealth individuals) not to become entrepreneurs. This result therefore supports the view that the relationship between individual wealth and entrepreneurship in advanced economies is driven at least in part by unobserved heterogeneity (in human capital or individuals' ability), rather than only due to talented, but less wealthy individuals who are unable to access capital for new ventures.

Second, the results in this paper provide an alternative explanation for the strong positive association between individual wealth and entrepreneurship among the very wealthy (Hurst and Lusardi, 2004) and the finding that even wealthy individuals (with liquid assets well beyond the needs to start a typical business) respond to unexpected increases in their assets by choosing to become entrepreneurs (Holtz-Eakin, Joulfaian and Rosen, 1994). While prior work has argued that this finding was evidence of a lower bound for financing constraints in entrepreneurship, the results from this paper suggest that at least part of the entry in entrepreneurship following large windfall gains for already wealthy individuals may be driven by the fact that theses individuals can now undertake low value entrepreneurial ventures that they aspired to found but may not have been able to finance before. This may also explain the strong positive association between wealth and entrepreneurship in the cross section even among the top $5 \%$ of the wealth distribution (Hurst and Lusardi, 2004) and is consistent with the finding that private equity returns seem to be too low (Moskowitz and Vissing Jorgensen, 2002). It is also consistent with findings that wealth and ability may be negatively correlated in certain populations (Jovanovic and Evans, 1989) and that returns to capital can be decreasing for the very wealthy (Hvide and Møen, 2007).

This result also has important implications for policy makers aiming to stimulate entrepreneurship by providing cheap credit for new ventures. A growing literature supports the view that entrepreneurs are not only critical for their role in creating new markets, technologies and products, but are equally important for their role in the process of "creative destruction" (King and Levine, 1993a; 1993b; Kerr and Nanda, 2007). While these potential positive externalities could justify a role for the government to stimulate entrepreneurship, the results from this paper suggest that a simple scheme of providing cheap credit for new ventures may be misguided. In particular, it may lead to adverse selection among entrepreneurs, where individuals who choose to select into entrepreneurship based on these subsidies may not always be talented individuals who lack funding for their ventures. A significant portion might instead include individuals with large non-pecuniary private benefits from entrepreneurship, rather than the projects that are typically seen as those that suffer from market failure (Scott Morton and Podolny, 1998).

Finally, the results in this paper highlights that the characteristics of entrepreneurs are endogenous to the financing environment and that there may be heterogeneity in the backgrounds and motivations of those who do choose to select into entrepreneurship. This has important implications for theoretical models of entrepreneurial choice, in particular for those who argue in favor of an 'entrepreneurial type'. It also suggests that making inferences about both the nature of entrepreneurship and the characteristics of entrepreneurs across regions or countries based on 
cross-sectional analyses may lead to erroneous conclusions, especially if the regions have very different institutional environments.

\section{References}

[1] Albaek, K. and Sørensen, B. E. "Worker Flows and Job Flows in Danish Manufacturing, 1980-91." Economic Journal, 1998, 108(451), pp. 1750-71.

[2] Astebro, T. and Bernhardt, I. "The Winner's Curse of Human Capital." Small Business Economics, 2005, 24, pp. 63-78.

[3] Bertrand, M.; Duflo, E. and Mullainathan, S. "How Much Should We Trust Differences-inDifferences Estimates?" Quarterly Journal of Economics, 2004, 119(1), pp. 249-75.

[4] Black, S. E. and Strahan, P. E. "Entrepreneurship and Bank Credit Availability." Journal of Finance, 2002, 57(6), pp. 2807-33.

[5] Blanchflower, D. G. "Self-Employment in OECD Countries." Labour Economics, 2000, 7(5), pp. 471-505.

[6] Blanchflower, D. G. and Oswald, A. "What Makes an Entrepreneur?" Journal of Labor Economics, 1998, 16(1), pp. 26-60.

[7] Braguinsky, S. and Ohyama, A. "Where does Entrepreneurship Pay?" mimeo, 2007.

[8] Carneiro, P. and Heckman, J. J. "The Evidence on Credit Constraints in Post-Secondary Schooling." Economic Journal, 2002, 112(482), pp. 705-34.

[9] Carroll, R.; Holtz-Eakin, D.; Rider, M. and Rosen, H. S. "Income Taxes and Entrepreneurs' Use of Labor." Journal of Labor Economics, 2000, 18(2), pp. 324-51.

[10] Cullen, J.B. and Gordon, R.H. "Taxes and Entrepreneurial Activity: Theory and Evidence for the U.S." NBER Working Paper 9015, 2002.

[11] de Meza, D. "Overlending?" The Economic Journal, 2002, 112

[12] Evans, D. S. and Jovanovic, B. "An Estimated Model of Entrepreneurial Choice under Liquidity Constraints." Journal of Political Economy, 1989, 97(4), pp. 808-27.

[13] Fluck, Z.; Holtz-Eakin, D. and Rosen, H. S. "Where Does the Money Come From? The Financing of Small Entrepreneurial Enterprises." Princeton Working Paper, 2000.

[14] Gentry, W. M. and Hubbard, R. G. "Tax Policy and Entrepreneurial Entry." American Economic Review, 2000, 90(2), pp. 283-87. 
[15] Gentry, W. M. and Hubbard, R. G.. "Entrepreneurship and Household Saving." Advances in Economic Policy and Analysis, 2004, 4(1)

[16] Gordon, R.H. "Can High Personal Tax Rates Encourage Entrepreneurial Activity?" IMF Staff Papers, 1998, 45(1), pp. 49-80.

[17] Hagen, K. P. and Sørensen, P. B. "Taxation of Income from Small Businesses: Taxation Principles and Tax Reforms in Nordic Countries," P. B. Sørensen, Tax Policy in Nordic Countries. London: Macmillan Presss, 1998, 28-71.

[18] Hamilton, B. H. "Does Entrepreneurship Pay? An Empirical Analysis of the Returns to Self-Employment." Journal of Political Economy, 2000, 108(3), pp. 604-31.

[19] Holtz-Eakin, D.; Joulfaian, D. and Rosen, H. S. "Sticking It out - Entrepreneurial Survival and Liquidity Constraints." Journal of Political Economy, 1994, 102(1), pp. 53-75.

[20] Hurst, E. and Lusardi, A. "Liquidity Constraints, Household Wealth, and Entrepreneurship." Journal of Political Economy, 2004, 112(2), pp. 319-47.

[21] Hvide, H.K. and Møen, J. "Liquidity Constraints and Entrepreneurial Performance." mimeo, 2007.

[22] Jensen, Arne Hauge. "Summary of Danish Tax Policy 1986-2002." Danish Finance Ministry Working Paper, 2002.

[23] Kerr, W. and Nanda, R. "Democratizing Entry: Banking Deregulations, Financing Constraints and Entrepreneurship." HBS Working Paper 07-033, 2007.

[24] Khilstrom, R. E. and Laffont, J. J. "General Equilibrium Entrepreneurial Theory of Firm Formation Based on Risk Aversion." Journal of Political Economy, 1979, 87(4), pp. 719-48.

[25] King, R. G. and Levine, R. "Finance and Growth - Schumpeter Might Be Right." Quarterly Journal of Economics, 1993a, 108(3), pp. 717-37.

[26] King, R. G. and Levine, R.. "Finance, Entrepreneurship, and Growth - Theory and Evidence." Journal of Monetary Economics, 1993b, 32(3), pp. 513-42.

[27] Lindh, T. and Ohlsson, H. "Self-Employment and Windfall Gains: Evidence from the Swedish Lottery." Economic Journal, 1996, 106(439), pp. 1515-26.

[28] Moskowitz, T. J. and Vissing-Jorgensen, A. "The Returns to Entrepreneurial Investment: A Private Equity Premium Puzzle?" American Economic Review, 2002, 92(4), pp. 745-78.

[29] Petersen, M. A. and Rajan, R. G. "The Benefits of Lending Relationships - Evidence from Small Business Data." Journal of Finance, 1994, 49(1): 3-37. 
[30] Rajan, R. G. and Zingales, L. "Financial Dependence and Growth." American Economic Review, 1998, 88(3), pp. 559-86.

[31] Scott Morton, F. and Podolny, J.M. "Love or Money? The Effects of Owner Motivation in the California Wine Industry." Journal of Industrial Economics, 2002, 50(4), pp. 431-56.

[32] Shane, S. "Prior Knowledge and the Discovery of Entrepreneurial Opportunities." Organization Science, 2000, 11(4), pp. 448-69.

[33] Sørensen, P. B. "Recent Innovations in Nordic Tax Policy: From the Global Income Tax to the Dual Income Tax," P. B. Sørensen, Tax Policy in Nordic Countries. London: Macmillan Press, 1998, 1-27.

[34] Stiglitz, J. E. and Weiss, A. "Credit Rationing in Markets with Imperfect Information." American Economic Review, 1981, 71(3), pp. 393-410. 
FIGURE 1: INDEX OF RATES OF ENTRY FROM EMPLOYMENT INTO ENTREPRENEURSHIP (1983-1997) 1983=100

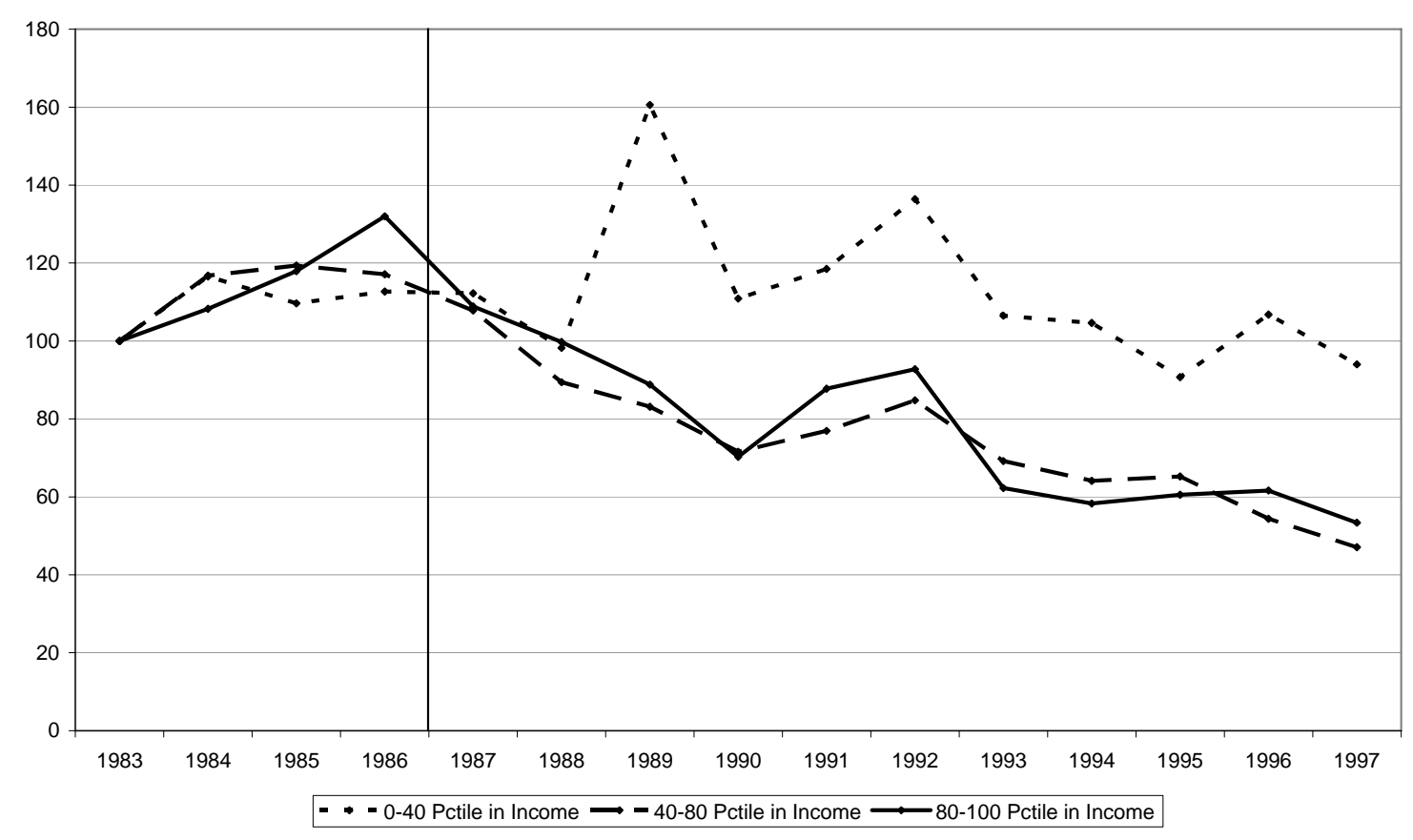


TABLE 1: DESCRIPTIVE STATISTICS*

\begin{tabular}{|c|c|c|}
\hline & $\begin{array}{c}\text { Become Entrepreneurs } \\
\text { in Subsequent Year } \\
(\mathrm{N}=12,253)\end{array}$ & $\begin{array}{c}\text { Don't Become } \\
\text { Entrepreneurs in } \\
\text { Subsequent Year } \\
(N=3,348,408)\end{array}$ \\
\hline \multicolumn{3}{|l|}{ Tncome and Wealth } \\
\hline Average Non Real Estate Household Assets (Constant USD) & 120,432 & 72,693 \\
\hline Average Household Debt including mortgage (Constant USD) & 110,293 & 58,963 \\
\hline Average Salary Income (Constant US Dollars) & 31,438 & 27,644 \\
\hline Average Total Income (Constant US Dollars) & 39,666 & 30,824 \\
\hline \multicolumn{3}{|l|}{ Demographics } \\
\hline Average Age & 36.3 & 37.1 \\
\hline Fraction Female & 0.25 & 0.47 \\
\hline Fraction Danish Citizens & 0.97 & 0.97 \\
\hline Fraction Married & 0.66 & 0.62 \\
\hline Fraction who have Children & 0.65 & 0.58 \\
\hline Fraction whose parents were previously Entrepreneurs ${ }^{* *}$ & 0.02 & 0.01 \\
\hline \multicolumn{3}{|l|}{ Highest Educational Degree } \\
\hline Compusory education & 0.25 & 0.31 \\
\hline High school (vocational) & 0.46 & 0.40 \\
\hline High school (academic) & 0.03 & 0.04 \\
\hline University & 0.26 & 0.25 \\
\hline \multicolumn{3}{|l|}{ Firm Size and Occpation Code in Which Employed } \\
\hline Average size of establishment where employed & 2,306 & 4,447 \\
\hline Median size of establishment where employed & 20 & 365 \\
\hline Fraction who are Directors or Top Managers & 0.03 & 0.01 \\
\hline Fraction who are Senior White Collar Employees & 0.21 & 0.11 \\
\hline Fraction who are Mid-Level White Collar Employees & 0.16 & 0.17 \\
\hline Fraction who are Low-Level White Collar Employees & 0.17 & 0.27 \\
\hline Fraction who are Blue Collar Tier 1 Employees & 0.20 & 0.16 \\
\hline Fraction who are Blue Collar Tier 2 Employees & 0.19 & 0.24 \\
\hline Fraction who are Other Employees & 0.05 & 0.04 \\
\hline \multicolumn{3}{|l|}{ Industry in Which Employed } \\
\hline Work in Agriculture & 0.05 & 0.02 \\
\hline Work in Manufacturing & 0.14 & 0.19 \\
\hline Work in Construction & 0.09 & 0.08 \\
\hline Work in Wholesale, Retail Trade & 0.22 & 0.13 \\
\hline Work in Transport & 0.07 & 0.06 \\
\hline Work in Finance, Insurance and Real Estate & 0.12 & 0.09 \\
\hline Work in Public or Private Services & 0.27 & 0.39 \\
\hline
\end{tabular}

\footnotetext{
* The Sample was constructed by identifying all individuals who started a new job in 1981 between the ages of 15 and 45 , and creating a pane dataset for these individuals for 15 years from 1982-1996 -- so that all individuals in the panel were between 15 and 60 over the entire sample period. Descritive Statistics are reported over the cells in which these individuals were employed at a firm -- that is years in which they were self employed, unemployed, or students are excluded from this table

** This variable takes a value of 1 if the individual's parents were entrepreneurs at any point between 1980 and 1982, but were NOT entrepreneurs in the year prior to the individual becoming an entrepreneur. This prevents a potentially spurious link between parents' entrepreneurship and an individual's own propensity to become an entreprenuer being driven family succession
} 
TABLE 2 : ESTIMATED PROBABILITY OF ENTERING ENTREPRENEURSHIP

Logit Regressions: Dependent Variable=1 if Individual Transitions to Entrepreneurship

\begin{tabular}{|c|c|c|c|c|c|}
\hline & \multicolumn{5}{|c|}{ Coefficients on Logit Model } \\
\hline & & Full Sample & & $\begin{array}{l}\text { Column (3) } \\
\text { including Self- } \\
\text { Employed }\end{array}$ & $\begin{array}{c}\text { Column (4) only } \\
\text { those with } \\
\text { University Degree }\end{array}$ \\
\hline Variable & $(1)$ & $(2)$ & $(3)$ & $(4)$ & $(5)$ \\
\hline Log Household Assets & $\begin{array}{l}0.059^{* *} \\
(0.006)\end{array}$ & $\begin{array}{l}0.062^{* *} \\
(0.006)\end{array}$ & $\begin{array}{l}0.085^{\star *} \\
(0.006)\end{array}$ & $\begin{array}{l}0.063^{* *} \\
(0.003)\end{array}$ & $\begin{array}{l}0.079^{* *} \\
(0.010)\end{array}$ \\
\hline Log Household Debt & $\begin{array}{l}0.080^{* *} \\
(0.006)\end{array}$ & $\begin{array}{l}0.053^{* *} \\
(0.005)\end{array}$ & $\begin{array}{l}0.041^{* *} \\
(0.005)\end{array}$ & $\begin{array}{l}0.030^{* *} \\
(0.003)\end{array}$ & $\begin{array}{l}0.018^{* *} \\
(0.007)\end{array}$ \\
\hline Log Salary Income & & $\begin{array}{c}-0.097^{* *} \\
(0.013)\end{array}$ & $\begin{array}{c}-0.061^{* *} \\
(0.012)\end{array}$ & $\begin{array}{c}-0.192^{* *} \\
(0.006)\end{array}$ & $\begin{array}{c}-0.147^{* *} \\
(0.014)\end{array}$ \\
\hline [40-80th Percentile of Total Income]=1 & & $\begin{array}{c}-0.253^{\star *} \\
(0.044)\end{array}$ & $\begin{array}{c}-0.301^{* *} \\
(0.045)\end{array}$ & $\begin{array}{c}-0.427^{\star *} \\
(0.023)\end{array}$ & $\begin{array}{c}-0.773^{\star \star} \\
(0.059)\end{array}$ \\
\hline [80-100th Percentile of Total Income] $=1$ & & $\begin{array}{l}0.330^{\star *} \\
(0.050)\end{array}$ & $\begin{array}{l}0.153^{\star \star} \\
(0.051)\end{array}$ & $\begin{array}{c}-0.266^{\star \star} \\
(0.028)\end{array}$ & $\begin{array}{c}-0.515^{\star \star} \\
(0.064)\end{array}$ \\
\hline Log Firmsize where currently employed & & & $\begin{array}{c}-0.186^{* *} \\
(0.005)\end{array}$ & $\begin{array}{c}-0.174^{* *} \\
(0.003)\end{array}$ & $\begin{array}{c}-0.171^{* *} \\
(0.006)\end{array}$ \\
\hline Tenure in Current Job (years) & & & $\begin{array}{c}-0.149^{* *} \\
(0.009)\end{array}$ & $\begin{array}{c}-0.168^{* *} \\
(0.006)\end{array}$ & $\begin{array}{c}-0.209^{* *} \\
(0.012)\end{array}$ \\
\hline Tenure in Current Job ${ }^{\wedge} 2$ & & & $\begin{array}{l}0.007^{\star *} \\
(0.001)\end{array}$ & $\begin{array}{l}0.006^{\star *} \\
(0.001)\end{array}$ & $\begin{array}{l}0.009^{\star \star} \\
(0.001)\end{array}$ \\
\hline Age & & & $\begin{array}{l}0.058^{* *} \\
(0.013)\end{array}$ & $\begin{array}{l}0.073^{* *} \\
(0.008)\end{array}$ & $\begin{array}{l}0.206^{* *} \\
(0.021)\end{array}$ \\
\hline Age $^{\wedge} 2$ & & & $\begin{array}{c}-0.001^{* *} \\
(0.000)\end{array}$ & $\begin{array}{c}-0.001^{* \star} \\
(0.000)\end{array}$ & $\begin{array}{c}-0.002^{\star \star} \\
(0.000)\end{array}$ \\
\hline Female & & & $\begin{array}{c}-0.652^{* *} \\
(0.030)\end{array}$ & $\begin{array}{c}-0.740^{* *} \\
(0.018)\end{array}$ & $\begin{array}{c}-0.633^{\star *} \\
(0.038)\end{array}$ \\
\hline Danish Citizen & & & $\begin{array}{c}-0.376^{\star *} \\
(0.056)\end{array}$ & $\begin{array}{c}-0.299^{\star *} \\
(0.034)\end{array}$ & $\begin{array}{c}-0.212^{\star \star} \\
(0.066)\end{array}$ \\
\hline Married & & & $\begin{array}{c}-0.069^{* *} \\
(0.026)\end{array}$ & $\begin{array}{l}-0.016 \\
(0.016)\end{array}$ & $\begin{array}{c}0.047 \\
(0.036)\end{array}$ \\
\hline Have Children & & & $\begin{array}{l}0.189^{\star *} \\
(0.025)\end{array}$ & $\begin{array}{l}0.091^{* *} \\
(0.015)\end{array}$ & $\begin{array}{l}-0.042 \\
(0.033)\end{array}$ \\
\hline Parents were previously Entrepreneurs ${ }^{1}$ & & & $\begin{array}{l}0.329^{* *} \\
(0.064)\end{array}$ & $\begin{array}{l}0.362^{* *} \\
(0.040)\end{array}$ & $\begin{array}{l}0.275^{\star *} \\
(0.090)\end{array}$ \\
\hline Highest Degree: Highschool (Vocational) & & & $\begin{array}{l}0.092^{* *} \\
(0.029)\end{array}$ & $\begin{array}{l}0.118^{* *} \\
(0.017)\end{array}$ & \\
\hline Highest Degree: Highschool (Academic) & & & $\begin{array}{c}-0.194^{\star *} \\
(0.061)\end{array}$ & $\begin{array}{c}-0.102^{* *} \\
(0.034)\end{array}$ & \\
\hline Highest Degree: University & & & $\begin{array}{l}-0.068 \\
(0.036)\end{array}$ & $\begin{array}{c}-0.131^{* *} \\
(0.024)\end{array}$ & \\
\hline Constant & $\begin{array}{c}-4.621^{* *} \\
(0.142) \\
\end{array}$ & $\begin{array}{c}-4.426^{* *} \\
(0.145) \\
\end{array}$ & $\begin{array}{c}-5.114^{* *} \\
(0.272) \\
\end{array}$ & $\begin{array}{c}-3.226^{* *} \\
(0.168) \\
\end{array}$ & $\begin{array}{c}-6.577^{\star *} \\
(0.468) \\
\end{array}$ \\
\hline Log Likelihood & -77700 & -76300 & -74100 & -166000 & -36000 \\
\hline $\mathrm{R}^{2}$ & 0.04 & 0.06 & 0.09 & 0.09 & 0.10 \\
\hline Number of Observations & $3,360,661$ & $3,360,661$ & $3,360,661$ & $3,360,661$ & 612,481 \\
\hline Number of Individuals & 270,674 & 270,674 & 270,674 & 270,674 & 52,040 \\
\hline Number of Transitions & 12,253 & 12,253 & 12,253 & 32,300 & 3,201 \\
\hline
\end{tabular}

Standard Errors in parentheses (clustered by individual); Two-sided t-tests: * $p<.05$ ** $p<.01$

Notes: Regressions include all Individuals in the sample who were employed between 1981 and 1996 . The dependent variable takes a value of 1 if the individual became an entrepreneur in the subsequent year. All Models include Year Fixed Effects, Industry Fixed effects at the SIC 1 level, Region fixed effects for each of 16 'Amts' or counties in Denmark, Occupation fixed effects to control for 7 levels of seniority in the organization -- such as directors, senior managers, white and blue collar workers.

1: This variable takes a value of 1 if the individual's parents were entrepreneurs in 1980 or 1981, but were NOT entrepreneurs in 1982 . This accounts for a potentially spurious link between parents' entrepreneurship and an individual's own propensity to become an entreprenuer being driven family succession 
TABLE 3 : PROBABILITY OF ENTERING ENTREPRENEURSHIP: INDIVIDUAL FIXED EFFECTS

\author{
Conditional Fixed Effects Logit Regressions. Dependent Variable=1 if Individual Transitions to Entrepreneurship
}

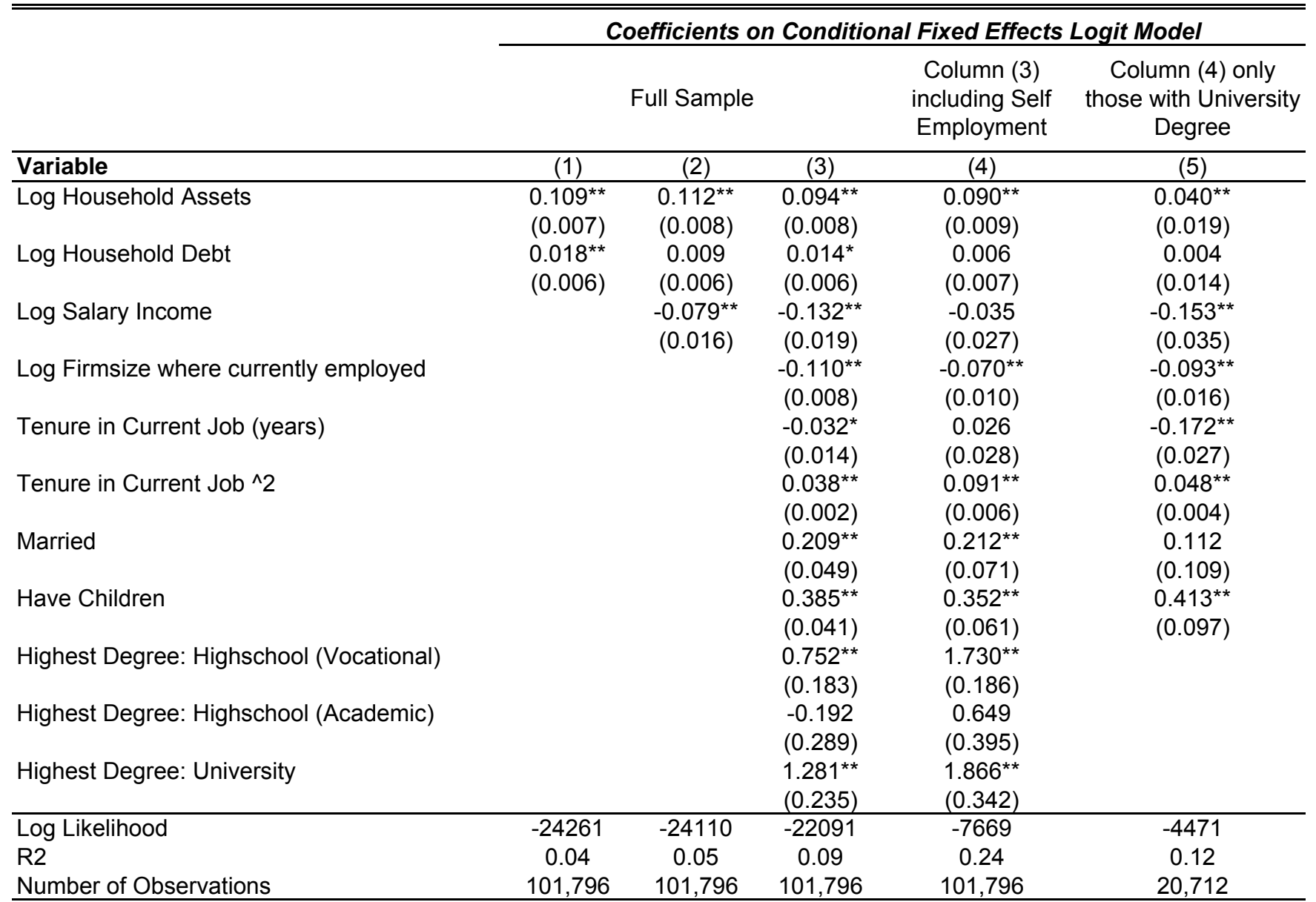

Standard Errors in parentheses (clustered by individual); Two-sided t-tests: ${ }^{*} p<.05^{* *} p<.01$

Conditional Fixed Effects Logit Models: Regressions include all Individuals in the sample who were employed between 1981 and 1996. The dependent variable takes a value of 1 if the individual became an entrepreneur in the subsequent year. Note that the sample is a panel but not all individuals are included in the regression in each year since I only include those who are employed at a firm in any given year. Industry Fixed effects at the SIC 1 level; Region fixed effects control for each of 16 'Amts' or counties in Denmark; Occupation fixed effects control for the level of seniority in the organization -- such as directors, senior managers, white and blue collar workers.

Notes: Models (3) and (4) are robstness checks using alternate definitions of entrepreneurship that includes both employers and self-employed individuals. Model (5) restricts the sample to individuals who had a university degree in 1981.

Because the models require variation in the dependent variable, individual fixed effects models can only be run on those individuals who eventually become entrepreneurs -- hence the number of observations in these models is significantly smaller; Also, since any variable that is correlated with time will perfectly predict entry (since for all of these individuals the period in which they enter into entrepreneurship is the last period in which they are observed) variables such as age are omitted; any variables that are fixed across individuals are also omitted as they are absorbed in the individual fixed effect. 


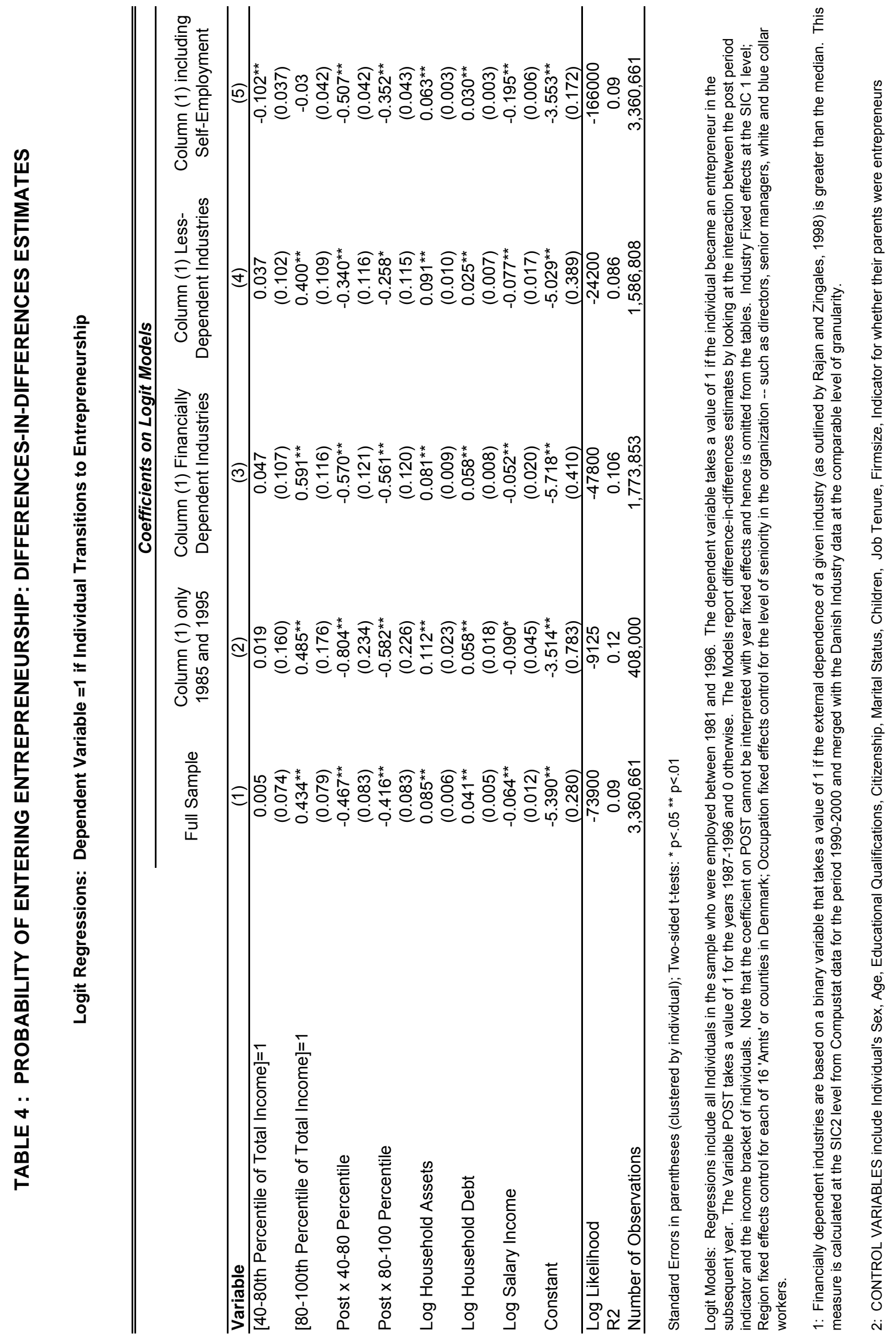




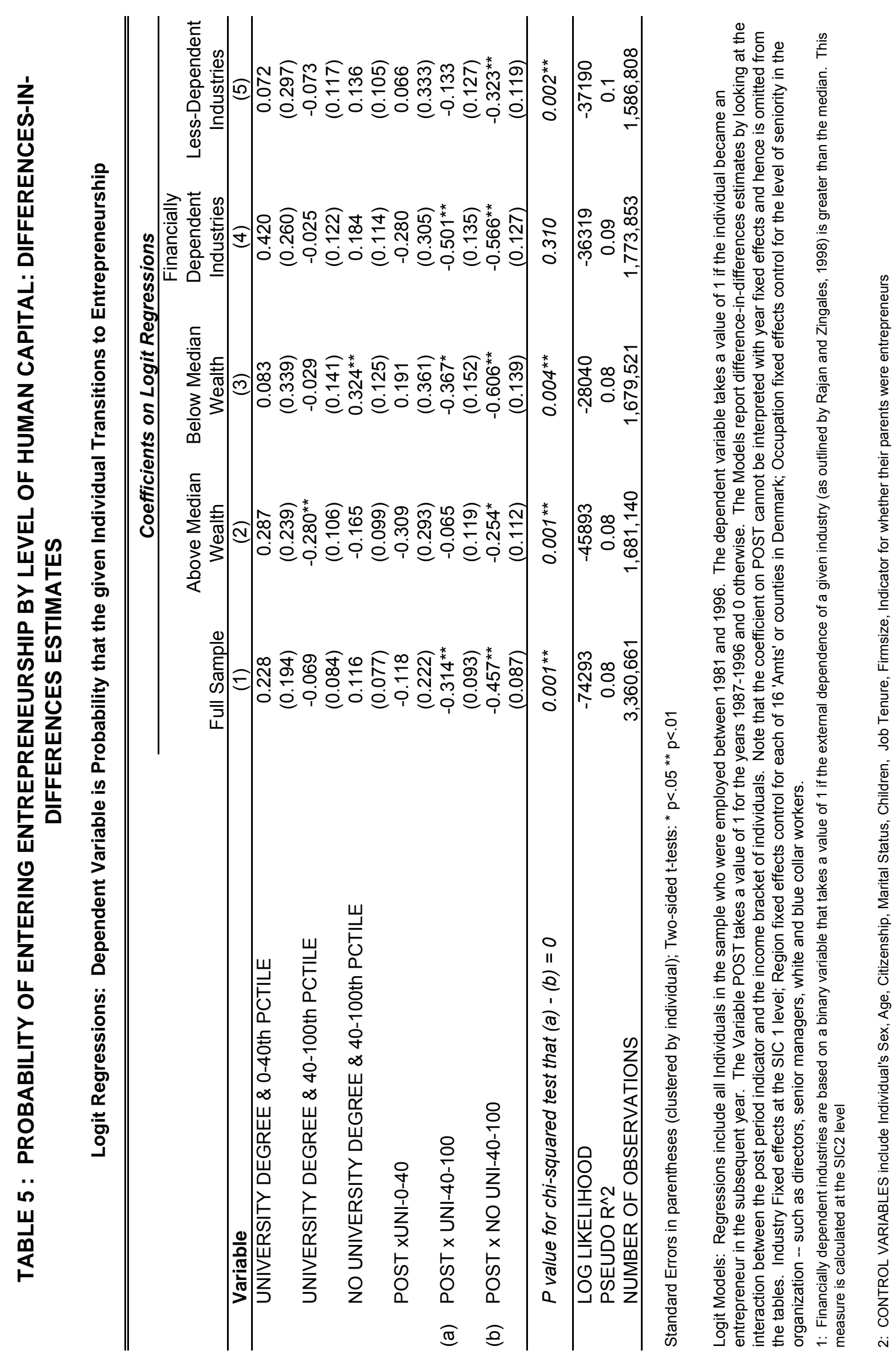




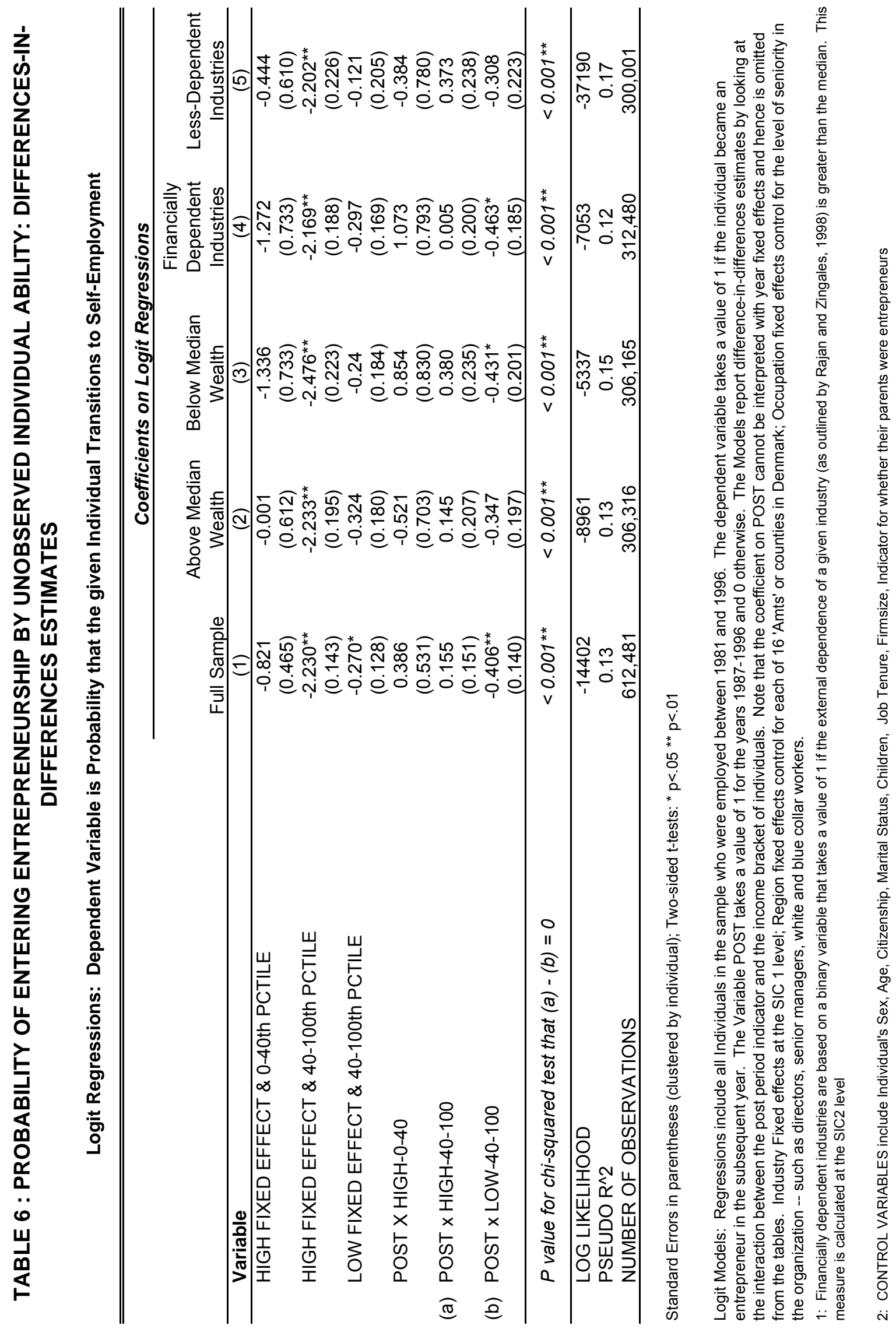




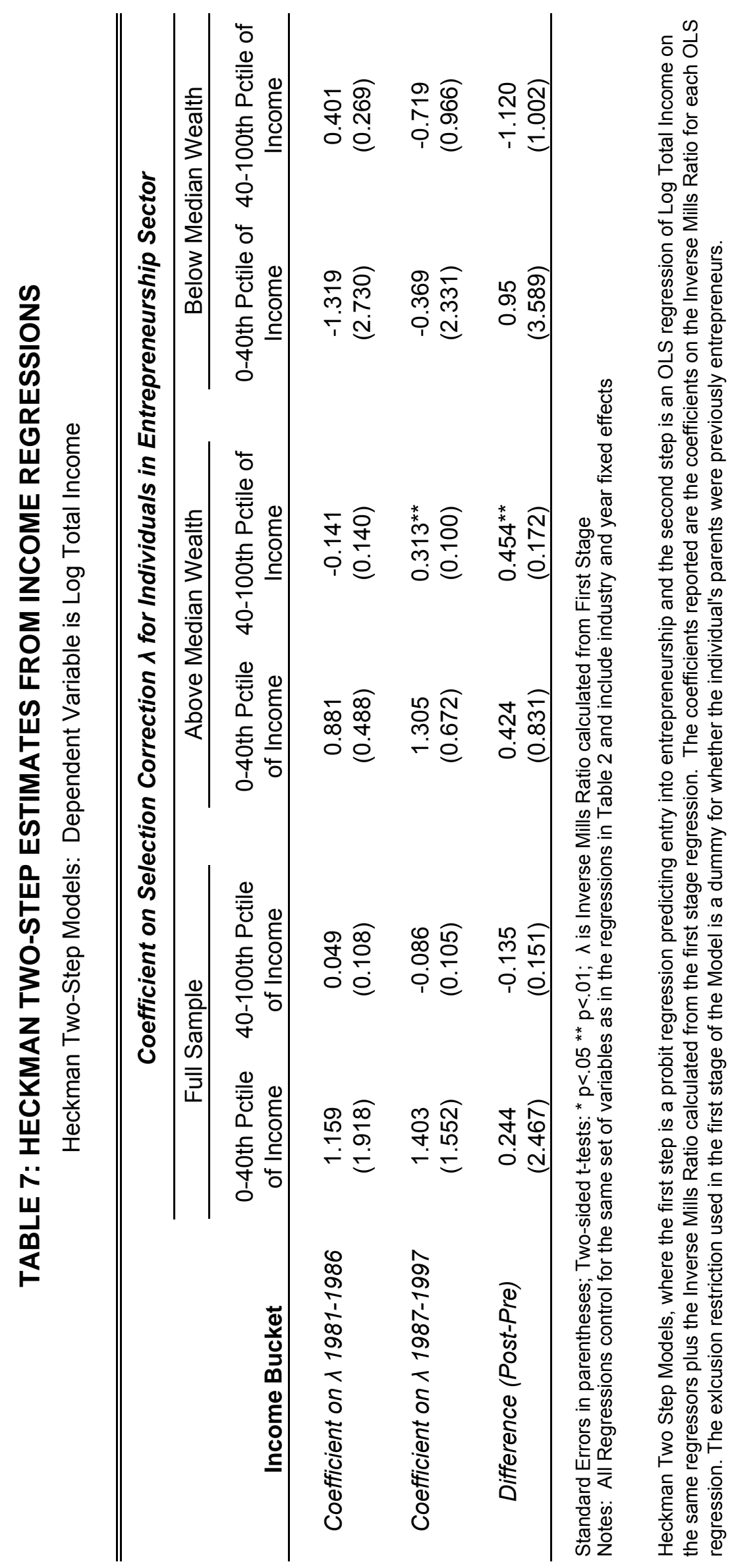




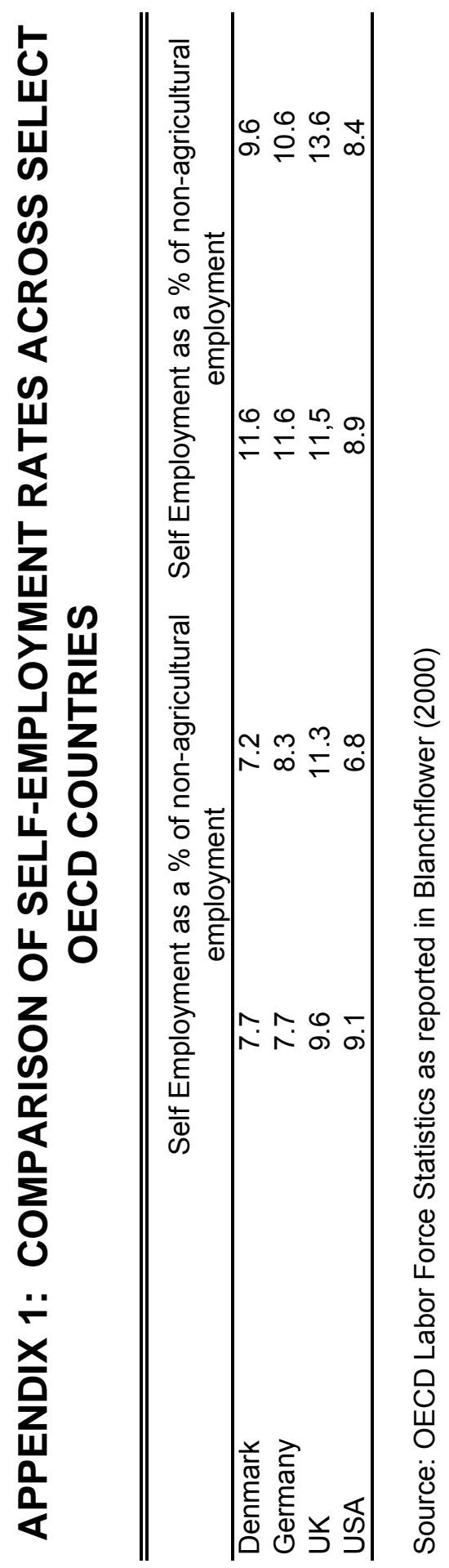






